\title{
Designing Web-based Library Management System
}

\author{
Tsega Weldu Araya \\ Ph.D. Students, School of Computer Science and \\ Technology \\ Northwestern Polytechnic University \\ Xian, China
}

\author{
Ass. Pro. Adhana Mengsteab \\ Dep. Head, School of Library and Information Science \\ Eritrea Institute of Technology \\ Mai -Nefhi, Eritrea
}

\begin{abstract}
This research paper's main target is to develop a computerized system that can accomplish the activities in the Asmara Community College of Education (ACCE) by providing easy access to library usage for librarians and users of the library. Although this system provides electronic documents like books, magazines, newspapers, and other useful files that can give access for the users without any restrictions and help librarians keep track of library information. Designing a computerized library management system (LMS) that would support to evacuate the problem encountered in the manual library. The physical library has many limitations to satisfy user's needs, and most hard copy documents are damaged after a limited time of usage. To eliminate the paperwork in the library, to reduce the high demand for the cost of books, and to avoid problems for missing files, we introduce a web-based LMS in ACCE. This will provide services for the entire citizens of the country in a different format without limitation of the period. The objectives of this research are to develop a system that can handle and manage the actions involved in the ACCE library efficiently and reliably which can be a benefit for the entire users to get access at their convenient time.

To overcome the above-mentioned limitations of the physical library, we are implementing this new technology to promote digital reading habits for users and to advance the knowledge of the users in every aspect of the technology. The users of ACCE Library have diverse age groups and professions. They require different kinds of documents for different purposes, like research studies, educational purposes, general knowledge, and for recreation. The Web-based Digital Library Management System (DLMS) will help to create a limitless amount of digital information and make it accessible to the world in parallel. This system planned to obtain research resources for the ACCE and then distribute it to users in their remote areas. The design parameters are Java Programming language, PHP, HTML, and Database MYSQL. Based on the challenges identified appropriate recommendations are prepared to improve the manual library services. Management system treaties with data entry, validation, and updates while the interactive system deals with system interaction with the users.
\end{abstract}

Keywords - Library Management System, ACCE, Database, Digital system

\section{INTRODUCTION}

ACCE (Asmara Community College of Education) is one of the colleges in Eritrea. ACCE library system provides everyday activity manually, which is recording data in a paper base. In most developing countries like Eritrea LMS are an integral part of the prompt and efficient to record detailed information of books and members.
In Eritrea, an effective information management system on traditional Libraries is very rare and many records tend to lose due to the lack of computerizes systems. For this project, we are proposing the development of LMS, [1] using ACCE Library as a case study. This system will provide the muchneeded information repository that the libraries need to be efficiently managed, which contains the relationships among admin, user, and members.

Presently, the transaction of books in the ACCE library has been prepared manually in most cases, thereby taking more time for a transaction like borrowing of books, returning books, searching for books, and adding new members. Series of difficulties have been occurring in the physical library because of this inefficient use in library management. Mostly human error happens in keeping records, like some manually written files loss and damaged due to inefficiency use. Nevertheless, the effort in the searching of books that could be labeled to be inadequacy in book Management is a problem in the manual library although causing disorganization and timeconsuming in the library. Correspondingly, space shortage for keeping records happens as the number of records added in the library, although the requirement for physical storage of files and records rises. If there is, no computerized system implemented the demand for the cost of books and records will remain a big challenge. Besides overcoming the cumbersome in the manual library, this newly designed computerized project approach [2] can be used to solve these problems.

\section{BACKGROUND}

A library is a structured collection of information sources [3] that are made accessible to the people. Library usually holds the information physically or in a digitized format. In the previous period, the access of library frequently used in the library room as the technology developed the access mode changed to computer system. Library is a fast-growing organism, however; the olden methods to maintain library systems are not dynamic and effective. The application of the modern system has become indispensable for prompt to retrieval and dissemination of information and improved service for the users.

LMS is an application that portraits a library system that can be generally small or medium in size. It is used and controlled by the library staff categorically to manage the library using computerized system [4] where librarians can record numerous transactions like the issue of books, the 
return of books, the adding of new eBooks, the adding of new members, etc. Books and user preservation modules are also involved in this system that would help to keep track of the users and a detailed description of the books that the library contains. Computerized system will help to avoid loss of books or members record; however, missing records mostly happens when a non-computerized system is used. This system is open access for all users however to some extent system maintenance and to generate different kinds of reports like lists of users registered, addition of eBooks and users return reports are only applicable to the admin. All these sections can help the librarian to manage [5] the library with more suitable and in a more effective way as compared to the manual library systems. This system is established and designed to support librarians to record all book transaction, to avoid and eradicate the problem of book loss and files in the library.

\section{LITERATURE REVIEW}

Those papers [6], [7] describes the advantage of using proper management in the information system and the sustainability of library systems. They mentioned that fast rising in different types of data creates difficulties to get accurate information. However, our system focuses on building more valuable information for the ACCE library users and the admin of the system have full control to manage the updated data. Library provides information and services that are essential to the learning and development of one's knowledge skills. Although we have a collaborative idea with their papers in maintaining, the long ran of the library system and information facilities.

This paper view management is explained by [8] "the art of performing things through people." A manager is noticed as a person who accomplishes the organization's goals by inspiring others to perform well. Moreover, there is a subjective question about whether management [9] is an art or a science; however, it can be said without a doubt that modern management in the environment of technology is becoming more of a science than an art. Moreover, we describe management for Management Information Systems (MIS) as the procedure for planning, organizing, staffing, coordinating, and controlling the efforts of the members of the organization to accomplish the commonly identified aims of the organization.

As Asmait Futsumbrhan explained that, a library is a place where a collection of books and other informational materials are made accessible to people for reading, study, or reference in their daily life activity. The library collections have almost contained a diversity of materials making it much easier for everyone who has an interest in reading and finding new things regarding their interests. Contemporary libraries preserve collections that contain printed materials such as manuscripts, books, newspapers, magazines, maps, and photographs. However, we found her explanation limited to the usage of the library. We are converting all the paperwork activities to a computer system and although adding a new eBook system, so the users can get access inside the library room and outside in digital format.
The focal task of a library is to collect, organize, preserve, and provide knowledge and information. In rewarding this mission, libraries preserve valued records of a culture that can convey over the following generations. Libraries are a crucial link in the communication among the past, present, and future generations. Whether the cultural record is limited in books or other Media, libraries must certify the record is preserved and made available for future use. Libraries provide for the users to get access to the information that is essential for work and learning. People in many professions use library materials to assist themselves in their daily work time. Although they use to gain information about their interest or to gain recreational materials such as films and novels. Scholars use library to supplement and boost their classroom proficiencies, to learn abilities in discovering sources of information, and to improve reading habits. One of the most valued activities of the library is to [10] provide information and services that are essential to the learning and development of one's knowledge.

According to Ato. Efrem Matiwos, director of the Asmara Public Library said, this newly introduced service is a great help for the readers saving time and energy. He further explained that having introduced this system is one-step forward in the library history and motivating to readers of the Library. However, their library system is more about public content because of its public library, which gives service to the community. Our findings will more focus on the needs of college students and instructors.

Concurrently to our research [11], this author explained the Library System as a fast-growing database for information retrieval, which targets in developing computerized systems to preserve the daily work of the library. Well, computerized library will be a benefit for users with fast and prompt services. Their library system denotes to the systematization of library maintenance and activities mainly used computerized. Their work has many structures that are mostly not available in manual LMS like facility of user login. In addition to the similarity of their work, we also proposed the digital archive, which can store the electronic files. This newly developed system has a capability of admin login through which the admin can monitor the whole system. Objectives of this study are to develop and build the database for the records and other facilities to the computer application. To provide numerous search selections to check the convenience of books in the Library to generate the list of books.

The author of this [12] paper uses the same idea as our paper in converting an analog format of records to digital format. Their research also covers converting multimedia documents but our paper limits to creating a digital platform for the books and changing library daily activities to a computerized system. Although the authors [13] of this paper briefly describe how to create a digital system, which has a higher acceptance rate and adoption with the users. Their focus was on decreasing the mismatches between system design and local user's realities. To satisfy our users and the library staff 
needs we are implementing a user-friendly web-based system.

\section{METHODOLOGY}

\section{A. Database Design}

Database design controls the duplication of data and it is the method of producing a comprehensive data model of a database. The data model consists of all the required conceptual, logical, and physical storage parameters required to create a design in a Data Definition Language (DDL). DDL is used to create a database. A completely attributed data model holds full attributes for each entity. The method of database design usually contains several stages that are supported out by database designers. Generally, the designer needs to follow those procedures:

\section{- $\quad$ Conceptual Design}

The objective of the conceptual design stage is to construct a conceptual model based upon the previously recognized requirements, but nearer to the final physical model. A commonly used conceptual model is known as an EntityRelationship (ER) model. Entity-Relationship Diagram (ERD) is a popular high-level conceptual data model. It is a complete, logical illustration of data or an organization for a business area. The E-R model is very crucial for mapping denotations and interactions of real-world enterprises onto a conceptual schema. The ERD Fig.1 shown below gives the entities in LMS, the relationship between the entities and attributes of both entities and their relationships. The ERD describes all data that are input, stored, transformed, and produced by the system. It also emphasizes solely on data objects, their attributes, and the relationships that connect different data objects.

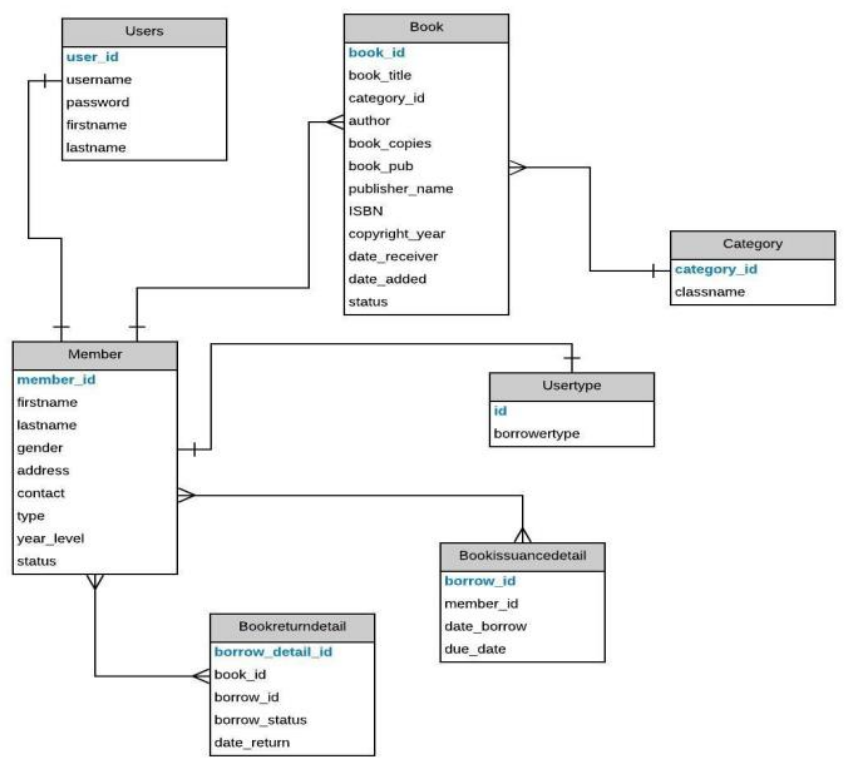

Fig. 1. Entity Relationship Diagram

\section{- $\quad$ Logical Design}

The development of logical design includes organizing data into a sequence of logical relationships known as entities and attributes. An entity denotes a piece of information. In relational database, an entity regularly maps to a table. An attribute is module of an entity and supports defining the exceptionality of the entity. In relational database, attribute maps to a column, however entity maps to raw.

\section{- Physical Design}

During this phase of design, the plan on how to build the tables, including appropriate data, types, field sizes, attribute domains, and indexes are described. The plan must express adequate details of the relevant fields that anyone can understand and use this plan to build a database. For this project, indexes and attribute domains are excluded from the physical design.

The conceptual design and logical design were independent of physical considerations. We are focusing on relational model and on creating database management system (DBMS) using MySQL, although our main focus is on those physical considerations.

\section{B. Architecture Design}

The phase of the design of computer architecture and software architecture is denoted as a high-level design. The model in selecting the architecture should understand all typical lists of modules, brief functionalities of each module, their interface relations, dependencies, database table, architecture diagram, and technology details, etc. The assimilation testing design [12] is carried out in a particular phase. After the necessities of the system are determined, the essential specifications for the hardware, software, data resources, and the information products that will satisfy the functional requirement of the proposed system can be determined. As shown in fig.2, this design will help as to outline for the entire system to identify and manage the connections of different sections.

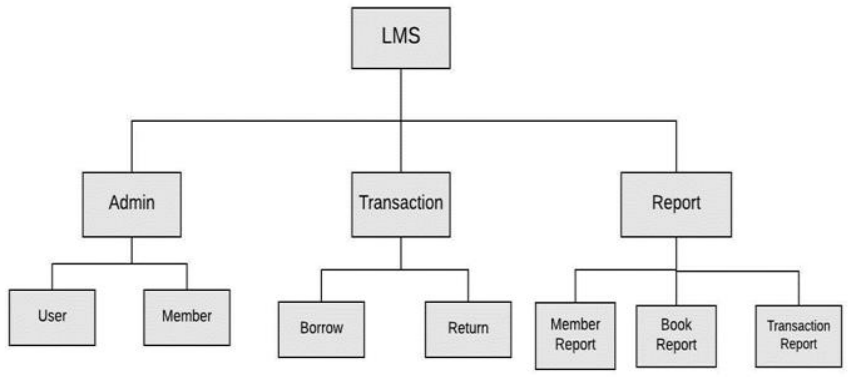

Fig. 2. Proposed system

\section{Interface Design}

User Interface (UI) Design emphasizes expecting what users want to do and confirming that the interface has features that are easy to access, understand, and uses to smooth those actions. This interface collects the concept from visual design, interaction design, and information architecture.

\section{Module design}

Module design level is mentioned as low-level design. The intended system is fragmented into smaller units or segments and each of them is explained, this indicates that the programmer can start coding. Fig.3 explained the flowchart of the entire system, which is the low-level design program 
specifications that have a full functional logic of the module in pseudo-code.

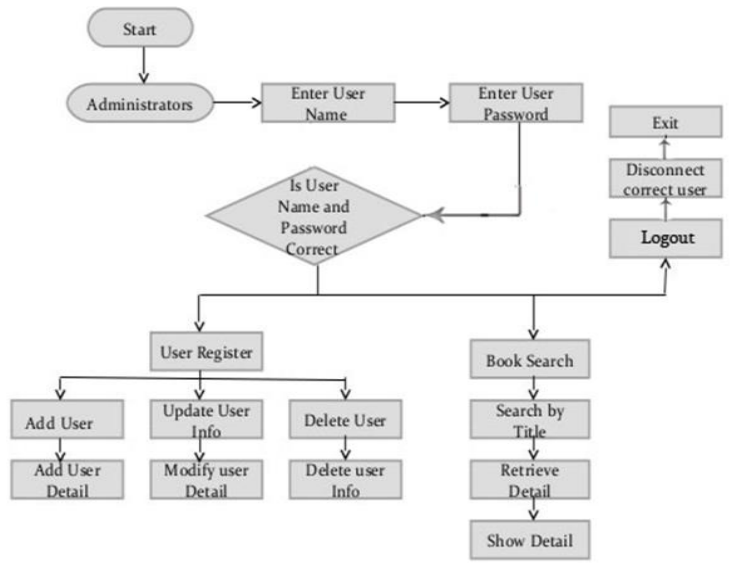

Fig. 3. Flowchart of the Proposed System

\section{EVALUATION METHOD}

The system testing process aimed to determine all defects in our project. This program was subjected to a set of test inputs and various observations were made and based on these observations it will be decided whether the program behaves as expected or not. Levels of testing: -

\section{A. Unit Testing}

In the V-Model, Unit Test Plans (UTPs) is developed in the module design phase. This UTPs are implemented to remove bugs at code level or unit level. A Unit is the smallest entity that can exist independently, e.g. program module. Unit testing confirms that the smallest entity can function appropriately even though it's separated from the rest of the codes.

\section{B. Integration Testing}

Integration Test Plans are implemented in the Architectural Design Period. These tests prove that unit formed and verified independently that can coexist and communicate among themselves. Test results are shared with the customer's group.

\section{System Testing}

System Tests Plans (STP) are developed in System Design Stage. Disparate Unit and Integration Test Plans, STP is composed of the client's business group. System Test certifies that expectations from an application designer are met. The entire application is verified for its functionality, interdependency, and communication. System Testing proves that functional and non-functional necessities have been met. Load and performance testing, stress testing, regression testing, etc. are subset of system testing.

\section{User Acceptance Testing}

User Acceptance Test (UAT) strategies are developed in the analysis phase. Test Strategies are composed of business users. UAT accomplished in a user environment that resembles the production of the environment, using accurate data. UAT proves that the delivered system meets the user's necessity and the system is ready for use in real-time.

\section{EXPERIMENTAL RESULTS}

In this section, we will discuss the results that are generated from the proposed system. Those results will help us to demonstrate that the proposed system provides access to users effectively and efficiently. Table.1 explains from the Test Plan of the system requirements, functional specifications, and design specifications to the relevant results. Although it is a benefit for the users to analyze the advantage of using a computerized system and the disadvantage of using a manual system.

\begin{tabular}{|c|c|c|c|c|}
\hline Test Case & $\begin{array}{l}\text { Test } \\
\text { Purpose }\end{array}$ & $\begin{array}{l}\text { Test } \\
\text { Condition }\end{array}$ & $\begin{array}{l}\text { Expected } \\
\text { Outcome }\end{array}$ & Actual Result \\
\hline Login & $\begin{array}{l}\text { Check } \\
\text { username } \\
\text { and } \\
\text { password }\end{array}$ & $\begin{array}{l}\text { If user details } \\
\text { are not } \\
\text { correct, } \\
\text { display error } \\
\text { message }\end{array}$ & $\begin{array}{l}\text { Grant access } \\
\text { to the } \\
\text { applicable } \\
\text { main system }\end{array}$ & $\begin{array}{l}\text { User successfully } \\
\text { logs into the } \\
\text { system upon } \\
\text { submission of } \\
\text { correct login } \\
\text { credentials. }\end{array}$ \\
\hline $\begin{array}{l}\text { Add } \\
\text { member }\end{array}$ & $\begin{array}{l}\text { To ensure } \\
\text { that a new } \\
\text { user is } \\
\text { added to the } \\
\text { system } \\
\text { successfully. }\end{array}$ & $\begin{array}{l}\text { If user already } \\
\text { exists in the } \\
\text { system, an } \\
\text { error message } \\
\text { should } \\
\text { display. }\end{array}$ & $\begin{array}{l}\text { New user } \\
\text { should be } \\
\text { successfully } \\
\text { added to the } \\
\text { system. }\end{array}$ & $\begin{array}{l}\text { If email address } \\
\text { entered already } \\
\text { exists in the } \\
\text { system, an error } \\
\text { message is } \\
\text { displayed. If the } \\
\text { email address of } \\
\text { the new member } \\
\text { does not exist in } \\
\text { the system, new } \\
\text { member is } \\
\text { successfully } \\
\text { added. }\end{array}$ \\
\hline Add book & $\begin{array}{l}\text { To ensure } \\
\text { that, is it a } \\
\text { new book or } \\
\text { copy is } \\
\text { added to the } \\
\text { system } \\
\text { successfully. }\end{array}$ & $\begin{array}{l}\text { If the book } \\
\text { already exists } \\
\text { in the system, } \\
\text { it will } \\
\text { increase the } \\
\text { number of } \\
\text { copies in the } \\
\text { system. }\end{array}$ & $\begin{array}{l}\text { Book should } \\
\text { be } \\
\text { successfully } \\
\text { added to the } \\
\text { system. }\end{array}$ & $\begin{array}{l}\text { If the book title, } \\
\text { author name, and } \\
\text { ISBN exist with } \\
\text { same record in } \\
\text { the system, then it } \\
\text { will increase the } \\
\text { number of copies. } \\
\text { However, if it } \\
\text { does not exist in } \\
\text { the system new } \\
\text { book is } \\
\text { successfully } \\
\text { added. }\end{array}$ \\
\hline $\begin{array}{l}\text { Transaction } \\
\text { module }\end{array}$ & $\begin{array}{l}\text { To ensure } \\
\text { that, is this } \\
\text { book } \\
\text { available in } \\
\text { the system } \\
\text { to borrow or } \\
\text { to return the } \\
\text { already } \\
\text { borrowed } \\
\text { books to the } \\
\text { system } \\
\text { successfully. }\end{array}$ & $\begin{array}{l}\text { If the book } \\
\text { exists in the } \\
\text { system, it can } \\
\text { be borrowed. } \\
\text { If not, we } \\
\text { must wait } \\
\text { until returned. }\end{array}$ & $\begin{array}{l}\text { Book should } \\
\text { be } \\
\text { successfully } \\
\text { borrowed } \\
\text { from the } \\
\text { system and } \\
\text { returned to } \\
\text { the system. }\end{array}$ & $\begin{array}{l}\text { If the book title, } \\
\text { author name, and } \\
\text { ISBN exist with } \\
\text { same record in } \\
\text { the borrowed } \\
\text { system, then we } \\
\text { must wait until } \\
\text { the book return. } \\
\text { However, if it } \\
\text { does not exist in } \\
\text { the system book } \\
\text { can successfully } \\
\text { be borrowed. }\end{array}$ \\
\hline Archive & $\begin{array}{l}\text { To ensure } \\
\text { whether the } \\
\text { e-books or } \\
\text { electronic } \\
\text { records were } \\
\text { successfully } \\
\text { added. }\end{array}$ & $\begin{array}{l}\text { If the e-books } \\
\text { exist in the } \\
\text { system then } \\
\text { the users can } \\
\text { use it, if not } \\
\text { we have to } \\
\text { add the e- } \\
\text { books to our } \\
\text { archive. }\end{array}$ & $\begin{array}{l}\text { E-books } \\
\text { should be } \\
\text { successfully } \\
\text { added to the } \\
\text { archive } \\
\text { system. }\end{array}$ & $\begin{array}{l}\text { If the e-book title, } \\
\text { author name, and } \\
\text { ISBN exist with } \\
\text { same record in } \\
\text { the system, then it } \\
\text { will display } \\
\text { already saved } \\
\text { message. } \\
\text { However, if it } \\
\text { does not exist in } \\
\text { the system new } \\
\text { ebooks are added } \\
\text { successfully to } \\
\text { the archive. }\end{array}$ \\
\hline
\end{tabular}


A database creates to store different kinds of files to the system. Although the database is designed to edit, delete, and to add documents at any interval of time. The given table. 2 table. 5 shows us the stored records of the LMS in different tasks. Those tables are useful to generate the required documentation of the proposed system. The database design of the user's table entails the user id, username, password, first name, and last name.
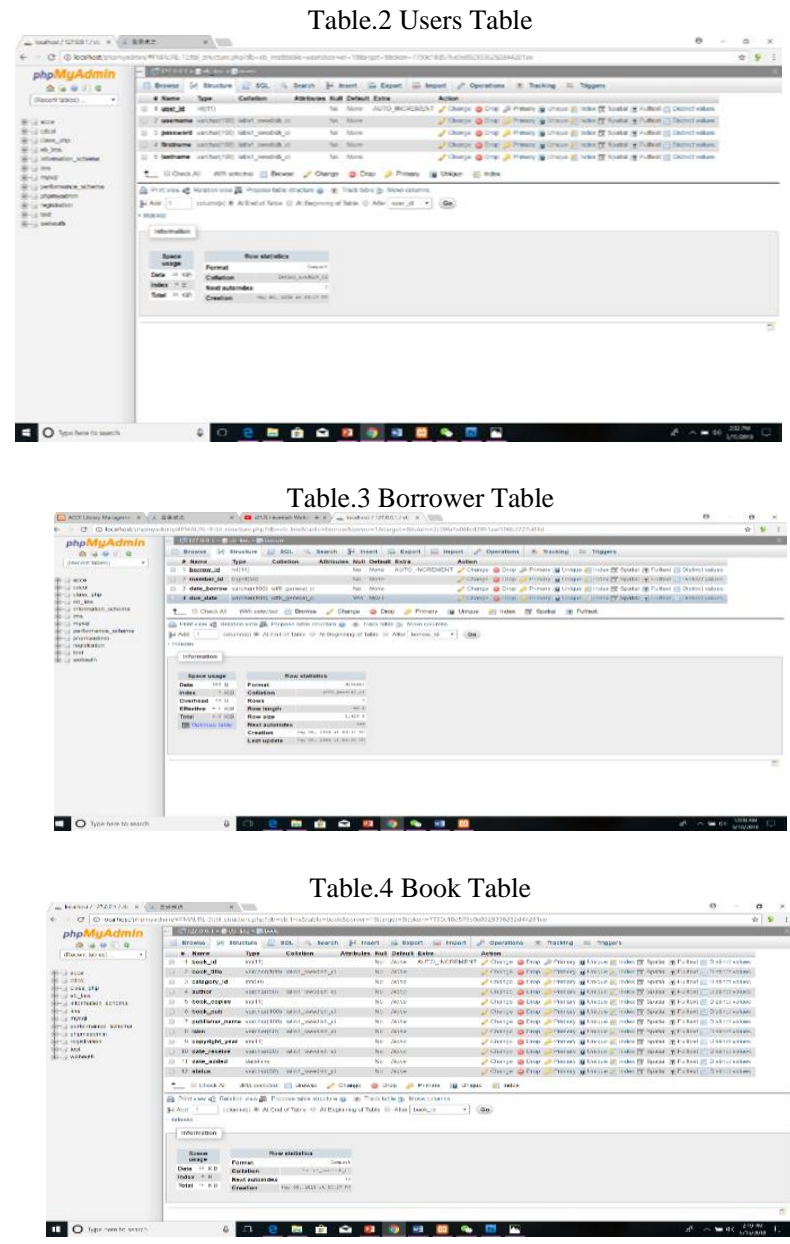

Table. 5 Lost book Table

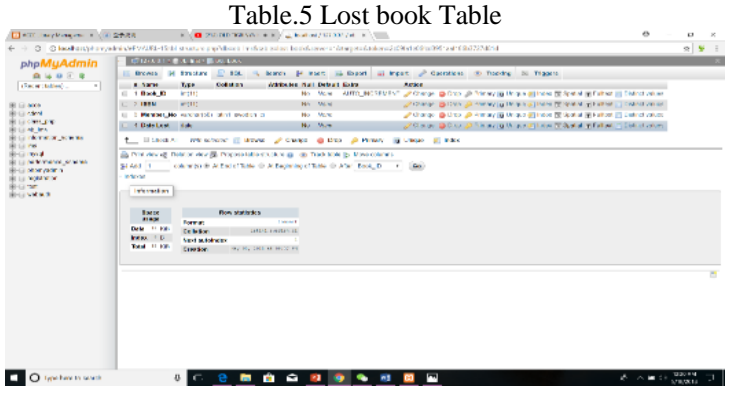

From fig.4 to fig. 8 illustrates the graphical interface of the LMS; it provides the basic page where the user and admin can click on, to access the library system. Fig.4 displays about admin login, the admin can log in with his /her username and password. While for the user login, a given user must have to register before getting access. As we see in fig.5 and fig.6, the activities of adding new members and adding new books are controlled by the library admin and by the librarians. Although the admin and the librarian have, the authorized access to add/edit/delete a book to the librarycomputerized archive. The library admin more like the librarian can add new books to the library system as much as possible to satisfy the user's needs and to improve for the user's reading habit. Fig.7 indicates the borrowing activity in the newly computerized LMS, the users of the library can borrow a book after being successfully registered into the system. Fig.8 shows us the electronic archive of all the downloaded books and any other magazines.

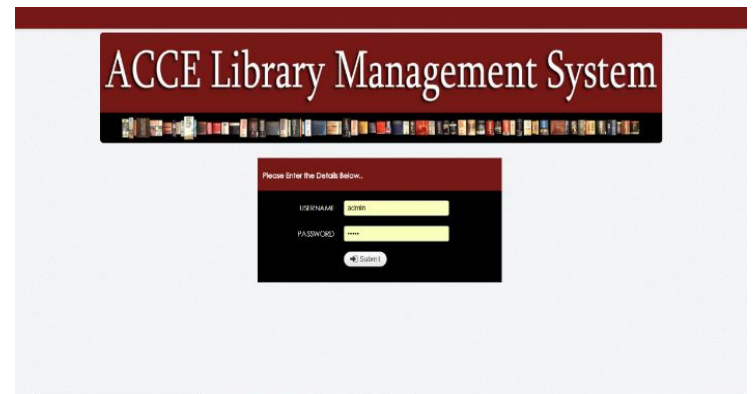

Fig. 4. Admin Login

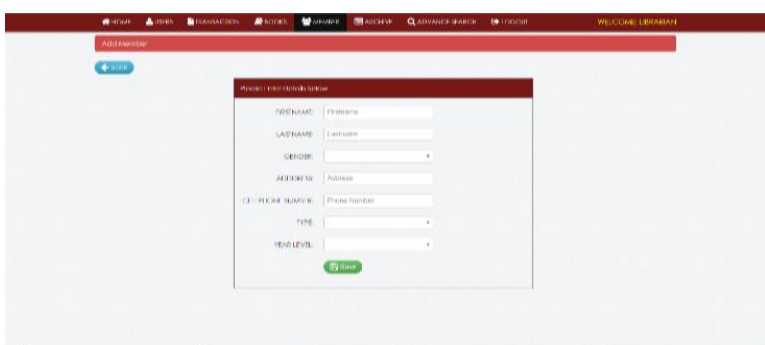

Fig. 5. Adding New Members

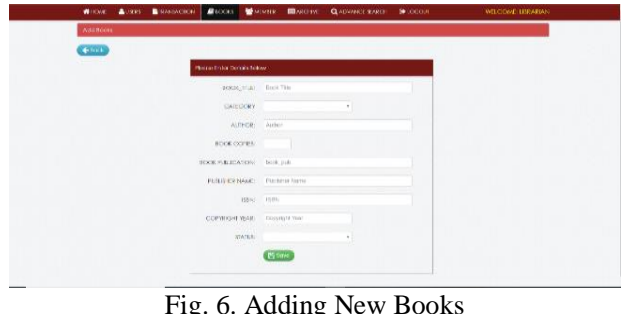

Fig. 6. Adding New Books

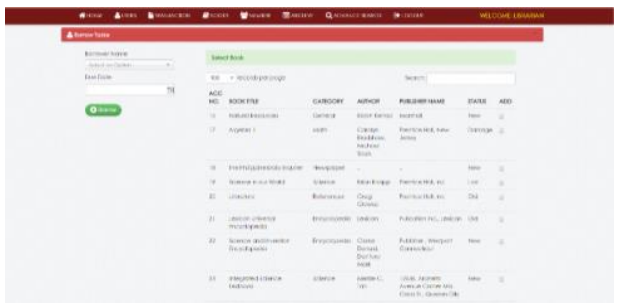

Fig. 7. Borrower Login

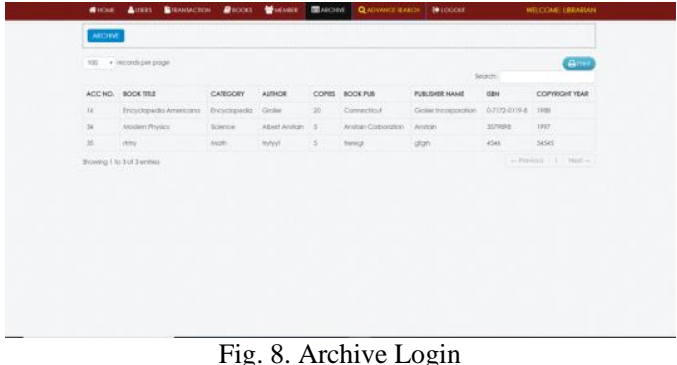

Fig. 8. Archive Login 


\section{CONCLUSION}

The mission to make life easier and processing faster has led to the computerization of various processes. Computer technology converted so many sectors especially the Educational sector. To foster technology-driven education, a Web-based LMS has been developed to manage all library operations such as adding new books, updating user's record and the process of borrowing books, etc.

In conclusion, from proper analysis and assessment of the designed system, it is safely determined that the system is an efficient, usable, and reliable LMS. It is working properly and adequately meets the minimum expectations which were proposed initially. The innovative system is expected to be a benefit to the users and staff in terms of efficiency in the usage of the library system. Although this system answers all the drawbacks of the physical library, in terms of information storage of the members in the database, it will provide fast generation of the member's report, and using this database, any files can be added, adjusted, deleted at any time. This computerized system performs the most sophisticated way to give access for the users in different forms although it provides electronic records via $\mathrm{Wi}-\mathrm{Fi}$ and the users can read an unlimited number of e-books at a time.

\section{REFERENCES}

[1] de Bem, R.M., and Coelho, C.C.d.S.R.: 'Applications of knowledge management in the area of librarianship and information science: a systematic review', Brazilian Journal of Information Science: research trends, 2013, 7, (1).
[2] Calanducci, A.S.: 'Enabling easy access to Grid storage services and digital repositories', 2014.

[3] Beynon-Davies, P.: 'Information systems: An introduction to informatics in organizations' (Palgrave Macmillan, 2002. 2002).

[4] Beynon-Davies, P.: 'Significance: Exploring the nature of information, systems, and technology' (Springer, 2010. 2010).

[5] Aloia, N., Concordia, C., and Meghini, C.: 'Implementing BRICKS, a Digital Library Management System', in Editor (Ed.)^(Eds.): 'Book Implementing BRICKS, a Digital Library Management System’ (2007, edn.), pp. 4-15.

[6] Harsh, S.B.: 'Management information systems', in Editor $(\text { Ed. })^{\wedge}($ Eds. $)$ : 'Book Management information systems' (Michigan State University, 2011, edn.), pp

[7] Rifaudeen, M.: 'Information management in libraries and its impact on sustainable library and information services with special reference to university libraries of Sri Lanka', 2015

[8] Sethi, N.K.: 'Mary Parker Follett: pioneer in management theory', Academy of Management Journal, 1962, 5, (3), pp. 214-221

[9] Moran, B.B., and Morner, C.J.: 'Library and information center management' (ABC-CLIO, 2017. 2017)

[10] Rizzo, J.R.: 'Management for librarians' (Greenwood Press, 1980. 1980)

[11] Kumar, H.V., Jayaram, M., and Vikas, S.: 'WEB-BASED DIGITAL LIBRARY MANAGEMENT SYSTEM', initiatives, 2017, 4, (2)

[12] Gustman, S.: 'Digital library system', in Editor (Ed.)^(Eds.): 'Book Digital library system' (Google Patents, 2000, edn.), pp.

[13] Park, N., Roman, R., Lee, S., and Chung, J.E.: 'User acceptance of a digital library system in developing countries: An application of the Technology Acceptance Model', International journal of information management, 2009, 29, (3), pp. 196-209

[14] Rotmianto, M., and Wahyudi, E.: 'Developing Plugin e-DDC as an Additional Application for Senayan Library Management System with PHP Language Programming and MySQL Database', Record and Library Journal, 2016, 2, (1), pp. 16-34 